\title{
HOXD11 wt Allele
}

National Cancer Institute

\section{Source}

National Cancer Institute. HOXD11 wt Allele. NCI Thesaurus. Code C97581.

Human HOXD11 wild-type allele is located in the vicinity of $2 \mathrm{q} 31.1$ and is approximately 6 $\mathrm{kb}$ in length. This allele, which encodes homeobox protein Hox-D11, plays a role in limb morphogenesis. 